This is the version of the article accepted for publication in New Political Economy published by

Taylor \& Francis https://www.tandfonline.com/doi/abs/10.1080/13563467.2017.1259300

\title{
Material Cultures of Water Financialisation in England and Wales
}

\section{Kate Bayliss, SOAS, University of London}

\section{$\underline{\text { Abstract }}$}

The ownership structure of the water and sewerage sector has changed substantially in England and Wales since the ten companies were listed on the London Stock Exchange in 1989. The majority of firms are now de-listed and a number of companies are now owned by financial investors via special purpose vehicles. In some cases, revenue streams from customer water bills have become securitised for decades into the future to raise funds for investment but also to finance distributions to shareholders. The high financing costs associated with these highly-leveraged corporate structures are passed on to customers. The regulator, Ofwat, tasked with protecting the interests of consumers, operates largely within a system of price controls intended to mimic a competitive market in the absence of financial speculation. This means that regulation steers away from intervening in the financialised corporate structures that have emerged around some of the water utilities. These manifestations of financialisation are considered to be 'market outcomes'. This paper explores the discourses and narratives that have developed in the provision of water in England and Wales to create a situation where such rentier transfers are normalised. Using the systems of provision approach, the paper shows that the material culture of water finance has been constructed along narrow lines with superficial consumer consultation while extensive financial engineering to increase shareholder returns continues unimpeded. 


\section{$\underline{\text { Introduction }}$}

This paper considers the material culture of financialisation in relation to the provision of water in England and Wales, EW. Since the industry was privatised, ownership stakes have changed hands and some water companies became owned by private equity investors. The sector has evolved considerably in the decades since privatisation. Some companies have become highly indebted and financial engineering has led to substantial returns generated from speculative activities, far removed from the production and distribution of water. Yet this is unchallenged and even normalised through the narrative of efficiency, investment and market outcomes. This paper considers the structures and cultures that underpin this normalisation. It draws heavily on a case study conducted for the European Union-funded FESSUD research programme (see Bayliss 2014 for more details).

Households mostly know little about the heavily financialised structure that lies behind their water consumption. For the vast majority of water consumers in EW, little appears to have changed in the way they consume water since privatisation, by the turn of a tap. While some may now have their consumption metered, many private water companies still have the same name as their public sector predecessors. This superficial continuity conceals substantial changes in the underlying social and economic relations of the sector. Largely, consumers are unaware that they are making significant payments to global financialised capital via their water bills.

This paper draws on the Systems of Provision (SoP) approach to explore the way in which relations between agents in the production and consumption of water 
interact to promote specific outcomes (for more on the SoP approach see Bayliss, Fine and Robertson 2013). The actors at different stages along the SoP engage in and experience financialisation ${ }^{1}$ differently depending on their position in the chain of provision and even their physical location in the country as there is considerable regional diversity in forms of water delivery. After a brief background review of some of the wider literature regarding water reforms in EW, the paper aims to highlight the ways in which financialisation has become embedded in the provision of water in EW, outlining the financial methods used to increase surplus extraction. Then, the paper explores the attitudes and cultures that are attached to this structure. This requires differentiating between the agents along the SoP. Private investors, the regulator and consumers all have evolved their own understandings and cultures so that financialisation is legitimised.

The paper shows that after more that 25 years of privatisation, the provision of water has fully entered circuits of global capital. Household water bills for decades into the future have, in some cases, become assets of private equity investors and have been repackaged and sold on via off-shore jurisdictions. Yet there has been scarcely a murmur of protest from any quarter. This is in sharp contrast with other parts of the world where much weaker forms of privatisation (with a fixed-term concession contract rather than divestiture) have resulted in major protests. In conclusion, the paper considers how an understanding of the material culture of finance for water sheds light on this (lack of) response.

\section{Background}

The privatisation of water has been bluntly described as part of a general process of 'accumulation by dispossession', a new round of enclosures of the commons and 
expansion of primitive accumulation (Harvey 2005; Bakker 2005; Ahlers 2010; Roberts 2008). However, privatisation in practice occurs differently across locations. Water in EW was privatised in 1989 by floating regional water and sewerage companies on the London Stock Exchange, LSE. Prior to this, water sector reforms in EW in the 1970s and '80s followed a pattern of neoliberalisation (see Fine et al. (2015) for more on neoliberalism) similar to that adopted across the world with water companies established at 'arm's length' from the government and price setting based on cost recovery principles (Bayliss 2013). However, the way in which privatisation was implemented in EW, with the complete divestiture of state companies, has not been adopted in any other country. In neighbouring Northern Ireland and Scotland, water has remained in public hands. Where privatisation was implemented elsewhere this has typically followed the French "affermage" model with the introduction of concession or lease contracts for the operation of the water infrastructure. Sometimes these are for long time periods but, ultimately, ownership of the infrastructure remains with the state. In EW, privatisation by divestiture was intended to be irreversible and to create a class of share owning investors. Water was one of a number of industries privatised in this way in the UK in the 1980s (Parker 2004). This mode of privatisation has been fundamental to the financialisation that has followed. Water privatisation was associated with a change in the ethos of water management in common with the expansion of neoliberalism more widely. Bakker (2005) charts the transition in the provision of water in EW from a post-war, 'state hydraulic' model, where policy emphasis was on the supply-led development of water infrastructure with largely state ownership of resources, to 'market environmentalism' where economic efficiency is prized over access or equity. 
Swyngedouw (2005, p.98) describes water privatisation as 'a process through which nature's goods become integrated into global circuits of capital' and privatisation is increasingly linked with financialisation. For example, Leyshon and Thrift (2007) refer specifically to the need for finance to ultimately drill down to real sector activity. They argue (p.98) that the 'bedrock' of financial capitalism is 'dependent on the constant searching out or the construction of new asset streams'. Such a predictable stream can be securitised and this allows borrowers to effectively realise their income streams 'early. They use the example of UK Private Finance Initiatives but, as this paper shows, it equally applies to the water sector. Allen and Pryke (2013) take up the theme of securitisation in their research into Thames Water. They describe a process of financialisation of water where 'households themselves are the financial asset' (p. 419). Such 'commoditisation' of both people and nature under capitalism increasingly shape social relationships (LeBaron 2010). ${ }^{2}$

Ekers and Loftus (2008) consider the politics of urban water provision through the lens of Gramsci and Foucault to show how (706), from a Gramscian perspective water infrastructure can be considered part of the hegemonic apparatus through which forms of 'common sense' in support of a specific group's interests come to be constituted. Meanwhile, from a Foucauldian approach, 'this entails managing the conduct of people and their relations with the material world, customs, beliefs and ways of acting and thinking'. They posit that everyday relations with water contribute to the maintenance of hegemony and the continuance of subtle forms of rule. Thus, water financialisation can be considered to be part of a wider project of social control. 
More specifically, Allen and Pryke assess the model of 'household securitisation' where household water bills become a financial asset of the company through policies such as those adopted by Thames Water. In attempting to understand why this is tolerated, they conclude that this model of financialised household water 'appears to be the subject of a political "ring-fence" where the regulatory body brokers agreement with investors over domestic water prices, service quality, water efficiency and the like, yet leave untouched the politics of packaging and selling households as a captive revenue stream' (p.420). They stop short, however, of trying to understand why the securitisation of water seems to be off limits for the regulator. This paper attempts to expand on some of these themes using the lens of the material culture of financialisation, and the 10Cs (see Introduction and Fine, this volume) to investigate the processes which have shaped the current system of provision and the cultures that sustain it.

\section{Financialisation in practice}

Concern is restricted, though, to the ten regional companies that provide water and sewerage services across England and Wales. ${ }^{3}$ Since the initial privatisation in 1989, the ownership structure has shifted considerably. Only three companies remain listed on the LSE. Owners of these listed companies are mostly institutional investors. For example, more than 95\% of Severn Trent shares are owned by financial institutions including insurance companies, nominee companies, banks, pension funds other corporate bodies, limited and public companies. ${ }^{4}$ Some of the largest investors have a stake in more than one utility (such as investment fund manager Blackrock Inc which has a stake in Severn Trent and United Utilities). 
Of the other seven water companies, one (Welsh Water) is owned by a not-forprofit company, two (Wessex Water and Northumbrian Water) are owned by large Asian conglomerates, and four are owned by SPVs put together by financial investors and, in most cases, listed off-shore. Details of the ownership of these companies are provided below:

- Yorkshire Water's ultimate parent company is Kelda Holdings Ltd registered in Jersey and owned by Deutsche Asset \& Wealth Management, Corsair Capital (described on the Kelda website as "a capital custodian for investors in infrastructure companies"), GIC Special Investments, the private equity arm of the Government of Singapore Investment Corporation and M\&G Infracapital Investments (part of Prudential Plc); ${ }^{5}$

- Anglian Water's parent company is Anglian Water Group Ltd, registered in Jersey and owned by Colonial First State Global Asset Management (part of Commonwealth Bank of Australia), the Canadian Pension Plan Investment Board, Industry Funds Management (a global asset manager owned by 30 Australian pension funds specialising in infrastructure, private equity, debt investment and listed equity) and 3i (an international investor focusing on private equity, infrastructure and debt management); ${ }^{6}$

- Thames Water's ultimate parent is Kemble Water Holdings Ltd owned by a consortium led by Macquarie European Infrastructure Fund II LP (MEIF2) owned by Australian Macquarie Group, with other stakeholders including Australian and Dutch pension funds, the Abu Dhabi Investment Authority, CIC the Chinese sovereign wealth fund, and the BT Pension Scheme; ${ }^{7}$

- Southern Water was bought from the Royal Bank of Scotland in 2007 by a consortium known as Greensands Holdings Ltd registered in Jersey with 
owners including IIF International SW UK Investments Limited (advised by JP Morgan Investments Inc.), the Northern Trust Company (Australian asset management firm), Phildrew Nominees (a subsidiary of UBS Global Asset Management), Sumaya Investments Ltd and various others including a Superannuation Fund from Papua New Guinea. ${ }^{8}$

Since privatisation, the sector has seen a marked increase in indebtedness of water companies. The level of gearing (the ratio of debt to equity) has increased substantially, although this has been more pronounced in some companies than others. The different company ownership structures have been associated with equally diverse financial practices. Typically the de-listing of a company from the LSE is associated with a reduction in public scrutiny of the operations of the firm, as the value of the share price gives an indication of how the market values different companies. But the de-listed companies owned by infrastructure conglomerates (Wessex and Northumbrian Water) appear to have more in common, in terms of corporate structures, with the companies that remain listed on the LSE than with the de-listed companies owned by financial investors.

A detailed review of the structure of the corporate groups, within which the regulated water utility is situated, indicates that the companies owned by infrastructure conglomerates and those listed on the LSE are associated with a 'flatter' group structure with just one or two intermediaries between the regulated company and the ultimate registered parent. The finance-owned companies, by contrast, have a long ladder of companies between the regulated water provider and the ultimate parent company. Most of these rungs in the ladder do little apart from receive and pay out interest and dividends to other companies in the group. Figure 1 shows an abbreviated diagram of the flow of such funds associated with 
Thames Water. Dividends and interest paid by the regulated utility on intergroup loans flow up the corporate chain before reaching the ultimate shareholders. The reality is more complicated than shown here. Research published in 2014 revealed nine companies between the regulated utility and the ultimate parent, Kemble Water Holdings Ltd as opposed to the four in this diagram (Bayliss 2014). INSERT FIGURE 1 ABOUT HERE

A similar pattern can be observed in the corporate group structures of the other financially owned companies (Anglian, Yorkshire and Southern Water). Another common feature of these four companies is that they have all carried out a process known as Whole Business Securitisation (WBS). This is a complex financial operation whereby finance is raised on the basis of future cash flows, the revenue stream from the payment of water bills in this case. These are packaged into a tradable financial asset and sold to investors. WBS requires certain covenants to be put in place to protect investors such as ring-fencing of the business segment that relates to the revenue stream. With these established, the creditworthiness of the firm is enhanced and they are able to increase their gearing levels while maintaining their credit rating. WBS is only possible where there is an extremely stable revenue stream for which the EW water companies are ideal.

Ironically, WBS was first used in the water sector to enable the not-for-profit Glas Cymru to take over Welsh Water, using debt to finance the acquisition in 2001. An additional part of this transaction required that a subsidiary group company be set up in the Cayman Islands in order to overcome the restrictions of UK corporate law regarding the raising of debt to facilitate an acquisition. This model was then followed by Anglian, Thames, Southern and Yorkshire Water. Using WBS and with a Cayman Island group company, these investors were able to buy water 
companies in large part using debt finance which was then added to the debts of the company (rather than staying with the investors). Since then, Welsh Water has paid off a considerable portion of its debt. Meanwhile, the finance-owned companies are now the ones with the highest gearing levels and the lowest credit ratings of the sector, although they are still a couple of notches above investment grade (Table 1), so they stay within the bounds of regulatory requirements on this criterion.

\section{INSERT TABLE 1 HERE}

The consolidation of acquisition debt is one reason for the increase in water company debts. Another reason is that these firms have also raised loans in order to pay dividends. Bayliss (2014) provides a detailed account of the transactions for Anglian, Yorkshire, Thames and Southern Water which have all increased gearing and delivered associated special dividends as a pay-out to shareholders, this often coinciding with the initial takeover. It is a theme that has been raised in several accounts of the sector although often only in passing (such as PWC (2013: 15); RiskMetrics (2008: 7); Allen and Pryke (2013: 426) and Turner (2013)).

Finally, another reason to increase debt is that interest is tax deductible (while dividends are not) so companies have an incentive to finance investment with borrowing rather than equity. These companies pay little tax due in part to their high interest payments, and the amount they pay in interest has soared since privatisation. This incentive is enhanced further where the loans are from shareholders at high rates of interest. The 2013 (81) accounts of the ultimate parent of Southern Water, Greensands Holdings Ltd, show interest of £67.9m payable to the shareholders on loans of $£ 633.9 m$. The 2013 accounts of Thames Water Utility Ltd (the regulated company) show that interest was paid to 
shareholders of $£ 17.5 m$ (TWUL Annual Report 2013: 75). In part, then the debts incurred are a means to provide further distributions to shareholders through (tax-deductible) interest payments.

The above demonstrates then that there is a heavily financialised structure to the production in some areas of water provision but that this varies across investor types. For consumers, though, the experience of financialisation is largely unseen. Few of the fifteen million Thames Water customers, for example, will have any idea that paying their water bill connects them to one of the largest Australian investment banks via a portfolio of European infrastructure funds. They are, however, beholden to these investors. Average household bills have increased by 40 per cent in real terms since privatisation (NAO 2013). Over the 2010-15 price review period, nearly 27 per cent of the average customer bill of $£ 360$ was paid for 'return on capital' (Ofwat 2011a: 8; Ofwat 2011b: 9). This is just to cover financing costs of interest and dividends and not actual investment. The water SoP generates a substantial transfer of revenue from households.

\section{$\underline{\text { Material cultures of water financialisation }}$}

The privatisation and financialisation of water creates a shift in the relations of economic and social reproduction. The transitions are experienced differently by the agents in the SoP. This section explores the way in which the ethos of financialisation is incorporated into the cultures of the stakeholders in the SoP. In so doing the paper makes selective use of the 10Cs set out in the Introduction to this volume in framing the material culture of water financialisation.

The discussion shows that the agents in the SoP have Contested priorities in the operation of the water sector. For investors, the provision of water is seen in terms of a source of profit. For consumers, water is an essential service and an item of 
household expenditure. While the consumer has an interest in an efficient and effective water supply, when it comes to pricing, the interests of these agents diverge. The regulator is supposedly tasked with mediating between these agents but the interests of investors would appear to be prioritised. This is justified on the grounds that what is good for investors is good for consumers. For example, according to Ofwat (2008: 1): 'A regulatory system that gives incentives to companies to be efficient, and to make profits, is in the best long-term interests of customers'. Thus the regulatory discourse is Construed so that the interests of consumers are merged with those of investors and the conflicts between agents overlooked.

\section{Water companies}

Water in EW is an attractive investment with an almost guaranteed revenue stream and a sympathetic regulator. In part this stems from the material culture of water which is vital for life and is an important input into other production processes. It often has no substitutes, provision is capital-intensive and largely monopolistic due to the high sunk investment costs. Furthermore, it is not a sector of rapid technological progress. Once a water system is established it can generate regular long-term financial inflows over a period of decades.

However, in many countries, water privatisation has not been widespread. Opposition to water privatisation usually stems from the strategic nature of water and its importance for social reproduction. In developing countries, privatisation efforts have been disappointing with firms reluctant to invest, in part because of fears of the contract being cancelled due to political pressure. There are no such concerns in EW. The culture of water privatisation is long-established and is replicated across other sectors such as energy and transport. The UK is planning 
to attract more infrastructural investment from the private sector in the coming decades so it is important that this is seen as an attractive destination for investment finance. This strengthens the position of water company investors as many also have stakes in other areas of infrastructure whether in the UK or globally. This unique Context has proved to be a fertile breeding ground for financialisation.

For private equity investors, water companies offer particularly profitable opportunities. Such buyers have a reputation for buying up firms and turning them around to make a quick profit using debt rather than equity investment as far as possible (for example, Cooper 2015). The 'sweating' of assets and raising debts to pay a special dividend to shareholders is common practice for such investors, and the same goes for adding acquisition debt to the company (Shaxson 2013). ${ }^{9}$ This was the approach adopted in the water sector and has led to considerable returns for investors. The financial gains are not always obvious. As mentioned above, shareholders received substantial 'special dividends' during the acquisition process but distributions are also realised through shareholder loans to the companies and with profits made on the sale of ownership stakes. Macquarie, for example, has sold off small parts of its stake in Thames Water for 'undisclosed sums'. These shareholder returns are not easily traced in standard financial reports. The high profits that can be earned from water investments are revealed in the high price that investors are willing to pay to acquire stakes in the companies, over and above the regulated asset value (RAV). Southern, Thames and Anglian Water were sold in the 2000s for 20-25 per cent over RAV, while Yorkshire Water fetched a 34 per cent premium (Utility Week 2009). In 2013, Severn Trent rejected a bid estimated to be a 27.8 per cent premium on the RAV 
(Bloomberg Business News 2013). For shareholders of listed water companies such a takeover offers considerable financial rewards. Listed water utility, United Utilities, saw its share price 'leap' in September 2015 when a broker indicated that it was an attractive acquisition target for a pension or infrastructure fund (Telegraph 2015). For these firms, then, EW water companies are profitable investments and regulation presents obstacles that at most need to be worked around. As Hildyard (2012) points out, for investors, the term infrastructure means a revenue stream rather than bricks and mortar.

The regulator: Ofwat

The Water Services Regulation Authority, Ofwat, was established at the time of privatisation. The primary tasks of Ofwat are designated to be to protect the interests of consumers, to make sure that water and sewerage companies carry out their functions observing the terms of their licence and to secure that the companies are able to finance their operations (known as 'financeability'). ${ }^{10}$ The main regulatory tool is price-cap regulation, devised in the 1980s and originally applied to the privatised telecoms and electricity industries. Prices are set in advance for a five-year period. Currently the 2015-2020 regulatory period has just started with prices that were set in the 2014 price review process (PR14). Prices for 2010 to 2015 were set in the 2009 Price Review process (PR09). The maximum price that each company can charge is multiplied each year by a factor, known as $\mathrm{K}$, as well as the increase in the RPI (water prices are inflation-proof).

Price cap regulation is supposed to encourage and harness efficiency in a way that other regulatory methods, such as rate-of-return regulation, do not. The idea is that where the price is fixed for a five-year period, companies have an incentive to increase productivity as they can retain the additional profits generated. At the 
end of the five years the regulator incorporates productivity improvements into the next price setting process so the gains are subsequently shared with customers. Rate-of-return regulation in contrast is considered to stifle innovation and productivity gains and instead incentivises firms to increase their costs with profits following in proportion.

The framing of the regulatory framework is in terms of intervening to weaken the scope for monopolistic exploitative practices. For example, Ofwat is required to promote effective competition wherever appropriate to protect consumer interests. The regulatory tools are intended to act as market forces might ideally perceived to do. By fixing prices in advance, water companies are supposed to be forced to act as price takers as they would be in an imaginary competitive market. Similarly, price controls are affected by firm performance against targets for meeting customer service standards. Where these are not met, firms see a reduction in the price they are allowed to charge. This is supposed to reflect the loss in revenue that would occur if customers were able to use an alternative source of supply.

However, this regulatory framework in practice involves mediating between agents with competing interests and contradictory objectives. Any solution has winners and losers and regulation is not neutral. The competing interests in the sector come out in the contestation over the value of $\mathrm{K}$, the factor by which prices can be adjusted. A small change in the value of $\mathrm{K}$ can have a significant effect on water prices and a large impact on company revenue. The calculation of $\mathrm{K}$ is highly complex and involves assumptions about future financing needs and costs as well as past performance against targets. The 2009 price review (where prices were set for 2010 to 2015) took place in the wake of the financial crisis, and there were 
concerns that financing costs would rise significantly. This fed into the setting of K. In practice, however, interest rates have remained extremely low and firms have benefitted from prices based on an assumed cost of capital that was higher than actual. In fact, the past three price reviews (covering a 15-year period) have been generous to water companies. The cost of debt has consistently been below that assumed in the price reviews by Ofwat (Ofwat 2013a), although the latest review (PR14), which set the prices from 2015 to 2020 looks set to lower prices slightly.

The role of Ofwat is presented as an external enforcer of rules but in practice the regulatory structure itself affects the ability of firms to meet the regulatory requirements so the relationship is not so simple. For example, Ofwat has a responsibility to ensure financeability, which means that prices need to be set at a level at which firms can still raise sufficient funds to finance investment. Firms also have a requirement to maintain a credit rating that is 'investment grade' as determined by external credit ratings agencies (Standard and Poors, Moody's and Fitch). But if firms increase their debts, this puts downward pressure on their credit ratings. Does the regulator then have to allow price increases to protect credit ratings? The boundaries of responsibility are blurred and complicated further because the regulatory framework itself has a major impact on the perceived creditworthiness of the water companies. The ability of firms to repay debts built on securitised water bills requires a highly predictable regulatory framework. Credit ratings agency, Moody's, raised concerns in the build up to PR14 that cuts in allowed returns for water companies would be 'credit negative' and the highly geared water companies (Anglian, Thames, Yorkshire and Southern Water) were the most vulnerable. ${ }^{11}$ The regulator is not external to the credit 
rating process and there are suggestions that the high debts of some companies offer protection against tighter regulation. According to Bloomberg Businessweek: 'The debt mountain at UK water companies is their best defence against politicians seeking to cut the cost of living' (Bloomberg News 2013). Research by OXERA, cited in Turner (2013: 48), also indicates that 'a significant number of investors believed that if companies took on more debt the regulator would be less likely to take action against them as action would be more likely to lead to the company experiencing financial difficulty'. There is a sense in which such water companies have become too indebted to be properly regulated!

The interplay of these complex relations then has a bearing on the outcomes of regulation which is far from a simple mechanical exercise of allowing for costs, incentivising innovation and sharing its benefits. Indeed, the regulator is effectively caught in a trap of allowing for financialised rewards to its companies or have the industry face increased financial costs with corresponding implications for subsequent pricing (with rewards going to lenders instead).

The mandate of the regulator to protect the interests of consumers and ensure financeability for companies is, however, conveniently broad and unspecific. In practice, the regulator intervenes selectively in some areas and steps back completely in others. One example of such selective intervention is the Revenue Correction Mechanism (RCM). The RCM highlights some of the contradictions emerging from attempting to force the provision of water into a 'market' structure. Across the sector there is a policy to increase the proportion of consumers that access water with a meter. This is intended to reduce water consumption, particularly in parts of the country that are water stressed (Ofwat 2013b). But where company revenue is earned on units sold, such a reduction leads to a fall in 
turnover and profits. In EW, this is overcome by the RCM. Under this policy, the price of water is adjusted in a price review period to account for over- or underconsumption in the previous period. If consumption falls, the price is increased in the next period. This is designed to overcome the disincentive that firms face to encourage households to reduce their water consumption.

This is, unsurprisingly, not made obvious to consumers, who are advised on how to keep their bills down. The Consumer Council for Water provides guidance on how to cut water bills by being water efficient. Advice includes installing a 'savea-flush' device in the toilet cistern; taking a shower instead of a bath; avoid overfilling the bath; and turning off the tap when brushing teeth (CCW 2013). But consumer advice should come with the caveat that, while your bill may fall in the current price review period, it will be increased in the next period so that water companies are not out of pocket.

While this seems to be a clear regulatory intervention to protect investors, the regulator opts elsewhere not to intervene, for example, in the capital structures of highly-leveraged firms. The very high debts of securitised water companies are potentially vulnerable to shocks and a threat to sustainability as there is no space to increase borrowing if necessary, quite apart from the interest costs to end users. Given that Ofwat is charged with protecting the interest of consumers, it is difficult to see any way in which this rent extraction by private equity firms is of any benefit to consumers.

But Ofwat does not want to intervene to prevent these 'market-led structures' (Ofwat 2011b). In a speech by the Chairman of Ofwat, Jonson Cox, it was stated: 'The regulator has previously taken the view that the capital structure of the companies (and consequent risks) is for the boards and shareholders to 
determine'. And this view continues as long as the water utility is not put at risk (Ofwat 2013: .9). On the contrary, rather than being alarmed by the rapid increase in gearing, this is seen as evidence of the strength of the regulatory regime, demonstrating a high level of confidence in the sector: 'Stakeholders have acknowledged this stable and transparent regulatory framework as a factor that has allowed the companies to sustain a relatively high level of gearing, but still maintain investment grade credit ratings' (Ofwat 2011b: 37).

Essentially, the regulator is permissive when it comes to financialisation. As long as the regulated utility meets its targets, what happens to financial structures is considered irrelevant. However, this amounts to tacit support for financialisation. Ofwat's position here is driven in part by a cultural attachment to incentive-based regulation even though, as shown above, the incentive created has been to increase profit via financial rather than productive innovation. But, secondly, Ofwat is not, and does not see itself, in a position to regulate these financial dealings. It is challenging enough monitoring the activities of the water utilities. Attempting to control the machinations of global private equity is beyond its scope and ambition. As Ofwat states, it is not designed to assess future financial failure as if a credit rating agency itself (Ofwat 2011b: 38). Finally, the culture of financialisation is greatly strengthened by the 'revolving door' between the industry and regulator. The Chairman of Ofwat, Jonson Cox, was awarded a payout of almost $£ 10 \mathrm{~m}$ when he left Anglian Water in 2010 in recognition of the increase in shareholder value during his time at the company (see, for example, Daily Express 2010). Cox was Chief Executive at the company when Anglian was taken over by private equity investors in 2006 when a special dividend of $£ 215 \mathrm{~m}$ was paid to shareholders and gearing increased to 83 per cent. ${ }^{12}$ Cox is therefore 
unlikely to challenge other firms operating in the same manner unless he were to become poacher turned gamekeeper.

\section{Financialised consumption and consumers}

The privatisation of water is associated with a shift in relations of social reproduction. For Bakker (2005: 548) 'consumer access is legitimated not by a citizen's entitlement to water as a service but by a customer's purchase of water as a quasicommodity. A reconfiguration of the hydrosocial contract between users and their environment is required'. However, most consumers have very little involvement in the industry beyond paying their bill, and water providers are largely invisible. A study on consumer attitudes to water, based on a series of workshops with water customers, found that most respondents had no idea who owned their water company (and many thought the owners were French). The corporate structure was largely unknown, not a high priority for respondents, and was not felt to impact on perceptions of value for money (Creative Research 2013).

Consumers are in no position to understand the financial practices taking place in the sector or their role in paying for this. The information is difficult to find and is obscured by a greater emphasis on superficial forms of customer engagement. For example, in extensive customer surveys conducted by the Regulator and the consumer body, the Consumer Council for Water (CCW), ${ }^{13}$ customers are asked questions such as how satisfied they are with their water. This generates findings, for example, that 75 per cent of customers are satisfied with value for money. Where customers feel that the water price they pay is unfair, this is mainly because it is perceived as 'expensive' or has risen. But customers are lacking information on which to base their views as they cannot know the costs on which their bill is 
based, and they are in no position to determine if the price they pay is fair. Such opinions are more likely to be derived from media campaigns and public relations efforts of companies, or simply that the tap works at relatively low cost compared to other necessities.

The issues of finance are out of reach for most consumers, instead being Collectively organised by a tight (Closed) group of agents including the water companies, the regulator and financial advisors. While CCW has achieved some success in navigating the complexities of finance on behalf of consumers, for example in providing input into consultations on the weighted average cost of capital in PR14 (ECA 2014), consumers are not invited to engage in debates on capital structures or securitisation or directors' remuneration. Consumer Challenge Groups (CCGs), established by water companies to approve company business plans for 2015-20, were not equipped to engage in any discussion on corporate finances. The CCG for Southern Water, when asked to comment on whether or not the shareholders are making returns which are fair, responded that they were not in a position to judge: 'the CCG is not the best body to answer this question' (SWCCG 2013: 24).

The result then has been a highly successful narrowing of Contestation to a manageable set of issues for companies. Glossy presentation gives the appearance of a customer focus with firms responding to customer needs. Water is increasingly Commodified and packaged as a consumer good. For example, in a survey for CCW, households are asked how likely they would be to recommend their water provider to friends and family in order to calculate what is termed a 'Net Promoter Score' (NPS). The overall NPS for water is 23. This is compared with results for Apple (69), First Direct (61), Sky (14), Churchill Insurance Company (- 
8), and the Royal Bank of Scotland (RBS) (-19) (CCW 2015). Thus, water is reinvented as a consumer good with customers a little less happy with their water than they are with their technology provider but more happy than they are with the scandalised bank, RBS. This survey information is gathered, analysed and presented even though there is no choice of water provider. But this kind of consultation has contributed to the cultural Construal of water as a Commodity like any other and the consumer as a customer.

There are, however, some increasing concerns about affordability with the proportion of households spending more than 5 per cent of their disposable income on water bills increasing from 8 per cent in 2002/03 to 12 per cent in 2011/12 (NAO 2013), amounting to about 2.7m households. Those that have trouble paying for water are, on the whole, the poorest and there is a statistically significant relationship between debt and deprivation (Ofwat 2011g: 27). Analysis by the debt charity StepChange found that water bill arrears were higher for female clients, for households with children, and especially lone parents (StepChange 2014). For the water companies and the Regulator, however, indebtedness is seen purely in business terms. Bad debts now add $£ 15$ to the average bill. There is some means-tested support for those that have problems paying. Water companies are now able to introduce 'social policies' in water pricing but this is subject to narrow provisos, including that the cost of social provision must not be more than the revenue saved from the introduction of such measures.

Although it is known that those that fail to pay their bills are on the whole the most deprived, non-payment is depicted to some degree as profligate, as for example in the title of the Ofwat web page, 'A drain on society - what can be done about water 
debt?'14 The angle taken by Ofwat is that: 'Consumer debt makes it more difficult and expensive for companies to finance investment in services. It also means that customers who pay their bills promptly are effectively subsidising those who do not. This raises difficult issues about fairness, particularly for those on low incomes who do manage to pay their bills'. Paying for water has become tinged with moral responsibility, with non-payment of bills Construed as depriving the sector of investment and exploiting hard-working households - as opposed to underpinning bloated returns to globally organised investment funds.

Consumers are crucial if passive agents in the financialisation of water. It is their regular payment of bills on which the whole architecture of securitisation rests. They are now financing significant payments to the financial sector in the payment of their water bills. The average water bill was $£ 396$ in 2014/15 (Ofwat 2014). Out of this, interest and dividend payments are around $£ 100$ a year per household.15 With 23 million households (ONS 2011) in EW that amounts to over $£ 2$ bn each year transferred from households to pay for returns on debt and equity for water companies (excluding non-household consumers). This is what feeds the global circuits of capital referred to by Swyngedouw (2005) and where speculative activity is anchored in real activity as outlined by Leyshon and Thrift (2007) attaching households to private financiers around the world. Yet consumers have no awareness of this. They are unwitting agents in the processes of financialisation. That consumers pay higher bills that provide revenue to finance securitisation and financialisation is not unique to water. However, the previous discussion shows that the sector is dominated by a culture of 'market outcomes' which is structurally skewed against consumers both in their bills proximately funding the costs of financialisation and their lack of access to knowledges of such 
practices. The regulatory function is inherently compromised by the need to remain investor-friendly combined with the weight and complexity of financial activity within the sector which takes place at an unobserved distance from the bills that appear through the letter box.

\section{Conclusion}

Opposition to water privatisation has sometimes sparked riots, most notably in Bolivia. Protests and poor delivery around the world have led to a number of privatisation contracts being terminated and water being renationalised (Kishimoto et al. 2014). In contrast, the lack of dissent around the financialisation of water in EW is striking. This paper has attempted to provide some insights into the cultures and structures that have allowed and even encouraged this feature of EW's water financialisation.

The Context has been significant. The way in which water was privatised, and the culture of privatisation across many sectors of the economy, has facilitated financialisation. In addition, the private water industry is long-established in EW. Hence investors have been able to rely on regulatory stability to boost securitisation revenues. The complexities of the sector are such that consumers have little option but to place faith in the Regulator to protect their interests. In some respects, consumers appear to have benefitted from the privatised water SoP over the years, receiving a good quality, regular water supply. The 2014 price review will bring prices down by around 5 per cent (before inflation) over the next five years.

However, this obscures the complexities of the underlying financial activities, as discussed above. Contestation has been channelled along the lines of narrow, superficial consumer consultations, and regulation is skewed to address specific 
issues such as capital costs, leakage and customer services at the expense of others. In particular, the securitisation of household bills and the influence of the financial sector remain unquestioned. But even if Ofwat wanted to control the financial extraction of private equity firms it is questionable if this would be possible, given the immense challenges that financial regulation raises in the wider economy.

The financialisation of water has also been noticeably absent from political debates. Some campaigners are supporting the re-nationalisation of the railways and energy companies, but most are silent when it comes to water. This could be due to the success of the water companies and Ofwat in emphasising the positives of privatisation in terms of the increases in investment and quality of water. According to Ofwat, water companies are currently investing around $£ 80$ million a week in maintaining and improving assets, and services and consumers have access to drinking water of excellent quality. ${ }^{16}$ There are also political issues involved. Stakeholders in water companies have interests in other infrastructure investments. For example, the Chinese government has a stake in Thames Water and is being courted for further infrastructure investments in the UK, not least the new nuclear power stations at Hinkley Point and beyond.

An additional factor may be that the complexities of ownership are too challenging and costly to unravel. For example, in March 2014 the total debts of the Kemble Water Finance Group, which owns Thames Water, came to over $£ 10.5$ bn (next to an operating income for Thames Water of just $£ 23.6 \mathrm{~m}$ in 2014 ) and incorporates numerous bond issues made by different group companies, some located in the Cayman Islands and some with a maturity date as far off as $2062 .{ }^{17}$ In the current economic climate there is unlikely to be any political appetite for devoting public 
funds to water re-nationalisation. This paper, then, shows the power of finance in shaping sector outcomes and that this is maintained by instilling cultures that normalise such practices. This hegemony is preserved with the consumer distanced from the financial operations of the sector and rent extraction treated as a 'market outcome' which can be interpreted as the new 'common sense', in the spirit of Ekers and Loftus (2008), discussed above.

To return to the theme of the 10Cs raised in the Introduction to this volume, and at various points, above, the material culture of water finance is Constructed around financialisation but Construed as if regulated market outcomes suffice with no grounds for these to be Contested despite private firms pushing for ways to extract surplus in the form interest and dividends. But decision-making around financing decisions are Closed with only token involvement of consumers, and water heavily Commodified, presented as a good like any other, and with the Regulator seeking to ensure that consumers Conform to this new form of water culture. Payment for water is Construed as a moral obligation with non-payment depicted as depriving the sector of investment finance and exploitative of the obedient customers that pay their bills. Context is significant with no other country operating their water in this way. Finally, water pricing is presented as a technical exercise but there are underlying Contradictory pressures that emerge from water conceived both as an essential commodity for all households and a source of profit for financial investors. The setting of tariffs is not neutral but results in specific distributional outcomes. 


\section{References}

Ahlers, R. (2010), 'Fixing and Nixing: The Politics of Water Privatization' Review of Radical Political Economics, 42 (2), pp. 213-230.

Allen, J. and Pryke, M. (2013), 'Financialising Household Water: Thames Water, MEIF and 'Ring-Fenced' Politics', Cambridge Journal of Regions, Economy and Society, 6 (3), pp. 419-439.

Bakker, K. (2005), 'Neoliberalizing Nature? Market Environmentalism in Water Supply in England and Wales', Annals of the Association of American Geographers, 95 (3), pp. 542-565.

Bayliss, K. (2013), 'The Financialisation of Water', Review of Radical Political Economics 20 (10), pp. 1-16.

Bayliss, K. (2014), 'The Financialisation of Water in England and Wales', FESSUD Working Paper No. 52. Available from: http://fessud.eu/wpcontent/uploads/2015/03/Case-study-the-financialisation-of-Water-in-

England-and-Wales-Bayliss-working-paper-REVISED annexes-working-paper-

52.pdf [accessed 26 October 2015].

Bayliss, K., Fine, B. and Robertson, M. (2013), 'From Financialisation to Consumption: The Systems of Provision Approach Applied to Housing and Water', FESSUD Working Paper No. 2. Available from: http://fessud.eu/financialisationconsumption-systems-provision-approach-applied-housing-water-2/ [accessed 26 October 2015].

Bloomberg Business News (2013), 'Severn Trent Rejects Sweetened Canadian, Kuwaiti Offer', 3 June. Available from: 
http://www.bloomberg.com/news/articles/2013-06-03/severn-trent-rejectssweetened-bid-from-canada-and-kuwait-group [accessed 26 October 2015].

Bloomberg News (2013), 'Debts Keep Water Firms Off-Limits for Politicians: UK Credit', 18 October. Available from: http://www.businessweek.com/news/201310-18/debts-keep-water-firms-off-limits-for-politicians-u-dot-k-dot-credit [accessed 26 October 2015].

CCW (2013), 'How to Cut Your Water and Sewerage Bills by Being Water-Efficient Advice for Domestic Customers', Information from Consumer Council for Water, Birmingham. Available from: http://www.ccwater.org.uk/wpcontent/uploads/2013/12/How-to-cut-your-water-sewerage-bills-by-beingwater-efficient.pdf [accessed 26 October 2015].

CCW (2015), 'Water Matters: Household customer' views on their water and sewerage services 2014', Report prepared by DJS Research for the Consumer Council for Water, Birmingham.

Cooper, C. (2015), 'Accounting for the Fictitious: A Marxist Contribution to Understanding Accounting's Roles in the Financial Crisis', Critical Perspectives on Accounting, 30 (July), pp. 63-82.

Creative Research (2013), 'Value for Money: A Report on Drivers of Satisfaction in the Water and Sewerage Industry' Report prepared for the Consumer Council for Water by Creative Research Ltd, London. Available from: http://www.ccwater.org.uk/wp-content/uploads/2013/12/Value-for-money-Areport-on-Drivers-of-Satisfaction-in-the-Water-and-Sewerage-Industry.pdf [accessed 26 October 2015]. 
Daily Express (2010), 'Jonson Cox's £10m payoff from Anglian Water' 15 November. Available from: http://www.express.co.uk/news/uk/211537/Jonson-Cox-s-10m-payoff-fromAnglian-Water [accessed 26 October 2015].

ECA (2014), 'Recommendations for the Weighted Average Cost of Capital 201520' Report submitted to the Consumer Council for Water by Economic Consulting Associates. Available from: $\quad$ http://www.ccwater.org.uk/wpcontent/uploads/2014/07/ECA-CCWater-Cost-of-Capital-summary-report.pdf [accessed 27 October 2015].

Ekers, M. and Loftus, A. (2008), 'The Power of Water: Developing Dialogues Between Foucault and Gramsci', Environment and Planning D: Society and Space, 26 (4), pp. 698-718.

Fine, B., Saad-Filho, A., Bayliss, K. and Robertson, M. (2015), 'Thirteen Things You Need to Know about Neoliberalism' FESSUD, Working Paper Series, no 155, Available from http://fessud.eu/wp-content/uploads/2015/03/13-Things-youneed-to-know-about-Neoliberalism-working-paper155.pdf [Accessed 30 September 2016].

Harvey, D. (2004), 'The 'New' Imperialism; Accumulation by Dispossession' Socialist Register, pp. 63-87.

Hildyard, N. (2012), 'More than Bricks and Mortar Infrastructure as Asset Class: A Critical Look at Private Equity Infrastructure Funds', Report for The Corner House. Available from: http://www.thecornerhouse.org.uk/resource/more-bricks-and-mortar [accessed 26 October 2015]. 
Kishimoto, S., Lobina, E. and Petitjean, O. (2014), 'Remunicipalisation as a Global

Trend', Report by Transnational Institute, PSIRU and Multinationals Observatory. Available from: https://www.tni.org/files/download/heretostay-en.pdf [accessed 26 October 2015].

LeBaron, G. (2010), 'The Political Economy of the Household: Neoliberal Restructuring, Enclosures and Daily Life', Review of International Political Economy, 17(5), pp. 889-912.

Leyshon, A. and Thrift, N. (2007), 'The Capitalization of Almost Everything: The Future of Finance and Capitalism' Theory, Culture and Society, 24 (7-8), pp. 97115.

Moody's (2013), 'UK Water Sector: Stable Outlook for Sector but Individual Companies Will Face Challenges', Industry Outlook, Moody's Investors Service, London.

NAO (2013), Infrastructure Investment: The Impact on Consumer Bill', Report by the Comptroller and Auditor General, National Audit Office, London.

Ofwat (2008), Water Charges and Company Profits: Position Paper, Ofwat, Birmingham. Available from: http://www.ofwat.gov.uk/consumerissues/chargesbills/pap pos watchrges200 80604.pdf [accessed 26 October 2015].

Ofwat (2011a), Cost of Capital and Risk Mitigants - A Discussion Paper, Report by Ofwat, Birmingham. Available from:

http://www.ofwat.gov.uk/future/monopolies/fpl/pap tec1106cocrisk.pdf [accessed 26 October 2015]. 
Ofwat (2011b), Financeability and Financing the Asset Base - a Discussion Paper, Report by Ofwat, Birmingham. Available from: http://www.ofwat.gov.uk/future/monopolies/fpl/prs inf1103fpl financeability. pdf [accessed 26 October 2015].

Ofwat (2013), 'Observations on the Regulation of the Water Sector', Lecture by Jonson Cox. Ofwat Chair Royal Academy of Engineering, March. Available from: http://www.ofwat.gov.uk/mediacentre/speeches/prs spe20130305jcrae.pdf [accessed 26 October 2015].

Ofwat (2013b), 'Water Meters - Your Questions Answered: Information for Household Customers'. Available from: http://www.ofwat.gov.uk/mediacentre/leaflets/prs lft 101117meters.pdf [accessed 26 October 2015].

Ofwat (2014) Press Release, PN09/12, 12 December 2014,. Available from: http://www.ofwat.gov.uk/mediacentre/pressnotices2008/prs_pn20141212finaldet [accessed 26 October 2015].

ONS (2011) Office of National Statistics 2011 Census

Parker, D. (2004), “The UK’s Privatisation Experiment: The Passage of Time Permits a Sober Assessment', CESifo Working Paper No. 1126, Centre for Economic Studies, Munich.

PWC (2103), 'Cost of Capital for PR14: Methodological Considerations', Report for Ofwat. Available from: https://www.ofwat.gov.uk/pricereview/pr14/rpt com201307pwccofc.pdf [accessed 26 October 2015]. 
RiskMetrics (2008), 'Infrastructure Funds: Managing, Financing and Accounting

- In Whose Interests?', Report by RiskMetrics Group. Available from:

http://www.maynereport.com/images/2008/09/01-13GEDV97N00.pdf

[accessed 26 October 2015].

Roberts, A. (2008), 'Privatizing Social Reproduction: The Primitive Accumulation of Water in an Era of Neoliberalism', Antipode 40 (4), pp. 535-560.

Shaxson, N. (2013), 'The Zombies of Mayfair', New Statesman Business Blog, 4 July.

StepChange (2014), Statistics Yearbook: Personal Debt 2014, Report by StepChange Debt Charity, London. Available from: http://www.stepchange.org/Mediacentre/Researchandreports/PersonalDebtSt atisticsYearbook2014.aspx [accessed 26 October 2015].

SWCCG (2013), 'Southern Water Customer Challenge Group Report to Ofwat' Worthing.

Swyngedouw E. (2005), 'Dispossessing H20: the Contested Terrain of Water Privatization', Capitalism Nature Socialism, 16 (1), pp. 81-98.

Telegraph (2015), 'Takeover Chatter Sends United Utilities Higher’ The Telegraph 7 September. Available from: http://www.telegraph.co.uk/finance/markets/ftse100/11848608/Takeoverchatter-sends-United-Utilities-higher.html [accessed 26 October 2015].

Turner, G. (2013), 'Money Down the Drain: Getting a Better Deal for Consumers from the Water Industry', Report for Centre Forum. Available from: http://www.centreforum.org/assets/pubs/money-down-the-drain.pdf [accessed 26 October 2015]. 
This is the version of the article accepted for publication in New Political Economy published by Taylor \& Francis https://www.tandfonline.com/doi/abs/10.1080/13563467.2017.1259300

Utility Week (2009), 'Ofwat Will Need the Wisdom of Solomon for PR09', Utility Week, 8 April.

${ }^{1}$ For a discussion on the meaning of the term 'financialisation' see Introduction and Fine, this volume.

${ }^{2}$ See Introduction to this issue for a more detailed specification of these processes of commodification with reference to the distinction between this and commodity form and commodity calculation.

${ }^{3}$ In addition there are nine smaller water-only companies, five local companies providing either water or sewerage services or both but these do not form part of the analysis of this paper.

${ }^{4} \mathrm{http}: / /$ www.severntrent.com/investors/shareholder-centre/shareholding-analysis ${ }^{5}$ http://www.keldagroup.com/about-us/our-investors.aspx

${ }^{6} \mathrm{http}: / /$ www.awg.com/investors/

${ }^{7}$ http://www.thameswater.co.uk/about-us/7565.htm - and Bayliss 2014

${ }^{8}$ Bayliss (2014).

${ }_{9}^{9}$ Shaxson describes the darker side of private equity investment, using the example of a hypothetical shoe company to show how cost cutting or asset sweating can save the company money and this cost saving can be used to raise debt. Then the debt is used to pay the owners a "special dividend" and firms use other means of financial engineering to direct the company cash flow to shareholders while minimizing equity investment: "And here's the fun part: you haven't taken on that debt, it's the shoe company that's now saddled with it".

10 This is an extreme simplification and for more on the role of Ofwat, see www.ofwat.gov.uk

11 https://www.moodys.com/research/Moodys-Highly-leveraged-UK-Water-Sectorcompanies-most-exposed-to--PR_292728 
This is the version of the article accepted for publication in New Political Economy published by Taylor \& Francis https://www.tandfonline.com/doi/abs/10.1080/13563467.2017.1259300

12 Anglian Water Services Limited Annual Report and Accounts (2007)

13 https://www.ofwat.gov.uk/regulating/aboutconsumers/sim

${ }^{14}$ Available at https://www.ofwat.gov.uk/publications/prs web 1002baddebt accessed 26 October 2015

${ }^{15}$ According to Ofwat (Ofwat 2011a, p.8, Ofwat 2011b, p.9) about 26.8\% of the average customer bill is paid for "return on capital".

${ }^{16}$ https://www.ofwat.gov.uk/industryoverview/today/achieve - accessed 22 October 2015.

${ }^{17}$ Kemble Water Finance Limited Investors Report for year ended 31 March 2014. 
This is the version of the article accepted for publication in New Political Economy published by Taylor \& Francis https://www.tandfonline.com/doi/abs/10.1080/13563467.2017.1259300

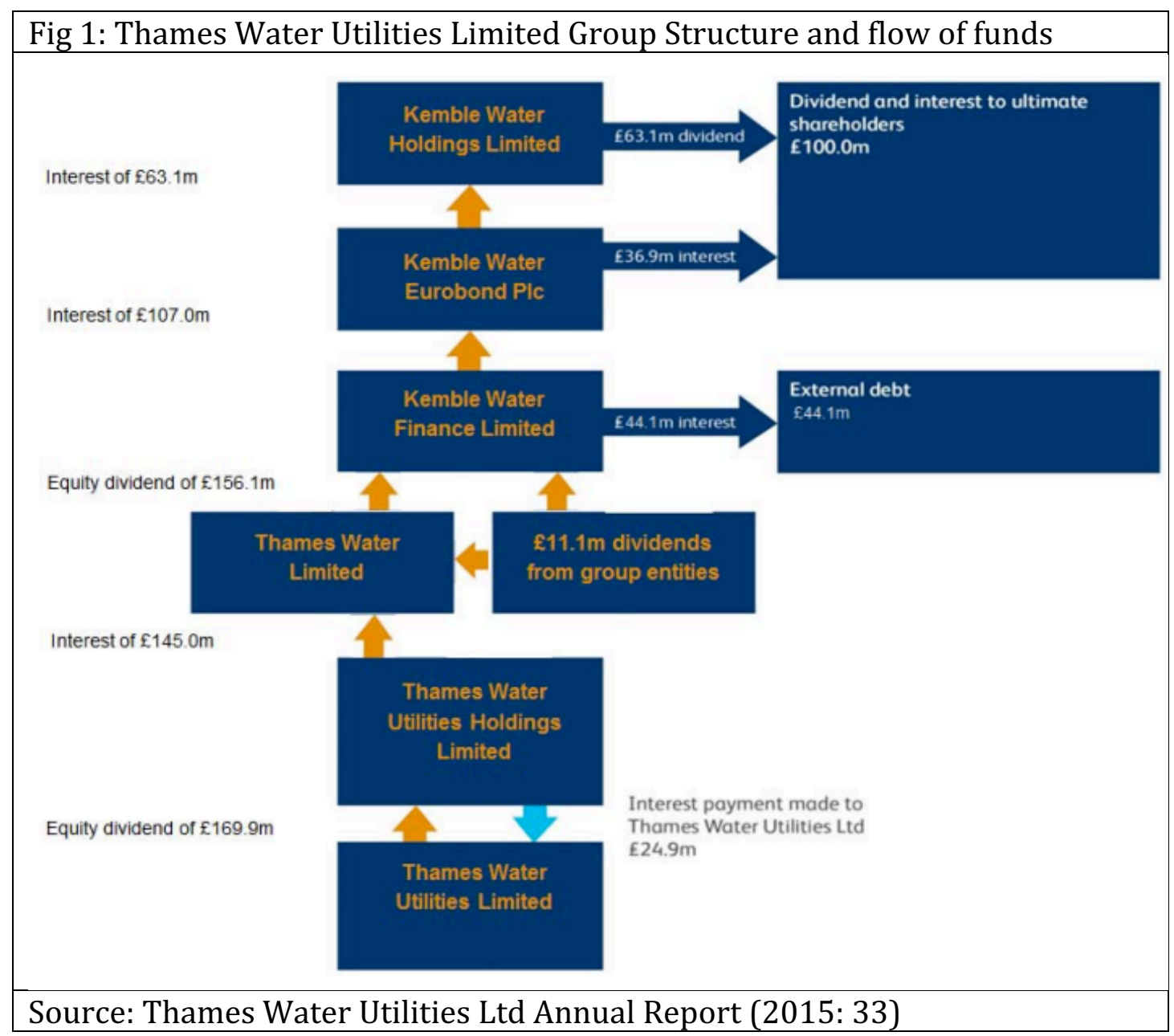


Table 1: Credit ratings and gearing levels for WaSCs

\begin{tabular}{|c|c|c|c|}
\hline $\begin{array}{l}\text { Credit } \\
\text { rating18 }^{18}\end{array}$ & Outlook & Company & $\begin{array}{l}\text { GEARING } \\
\text { Net } \\
\text { debt/RAV }\end{array}$ \\
\hline A3 & Stable & Dwr Cymru (Welsh Water) & 61.7 \\
\hline A3 & Stable & United Utilities Water Plc & 62.7 \\
\hline A3 & Stable & Severn Trent Water Ltd & 66.7 \\
\hline A3 & Stable & Wessex Water & 68.1 \\
\hline Baa1 & Stable & Northumbrian Water Ltd & 70.4 \\
\hline Baa1 & Stable & Thames Water Utilities Ltd & 79.0 \\
\hline Baa1 & Stable & Anglian Water Services & 80.4 \\
\hline Baa1 & Stable & Yorkshire Water Services Ltd & 82.6 \\
\hline Baa2 & Negative & Southern Water Services Ltd & 81.3 \\
\hline
\end{tabular}

Source: Moody's 2013

${ }^{18}$ Based on corporate family and not class of debt. 